\title{
What a Tangled Web We Weave: Conflicts in Rating Agency Liability
}

\author{
Nicholas Hoggard
}

\begin{abstract}
Regulation (EU) 462/2013 imposes civil liability upon credit rating agencies for causing loss to investors by virtue of intentional or grossly negligent infringement of certain regulatory requirements. This article argues that this regulation does nothing more than replicate the UK's existing law on deceit, albeit that it is (inexplicably) more restrictive for claimants. Further, it considers the potential harm to taxonomy and-by extension-to the rule of law caused by such legal duplication when resorting to very specific harmonisation measures.
\end{abstract}

\section{Keywords}

Credit Rating, Deceit, Fraud, Tort, Regulation, Taxonomy, Misstatement

Of the many causes attributed to the credit crisis, few have received more attention than the role of credit rating agencies (CRAs). A small number of large CRAs dominate an industry whose judgement on the credit-worthiness of debt obligations informed the investment decisions of banks and investors the world over. In this paper, I consider the latest in a line of EU Regulations dealing with CRAs. These regulations include Regulation (EU) 462/2013 of 21 May 2013 amending Regulation (EC) 1060/2009 on credit rating agencies [2013] OJ L146/1 (the Regulation). The Regulation imposes civil liability upon CRAs for causing loss to an investor by committing any of a significant number of infringements. ${ }^{1}$

In Part 1 of the paper, I submit that, while this civil liability replicates the existing UK law of deceit almost exactly, it is more restrictive than the law of deceit, in that it requires the defendant's reliance to be reasonable. In Part 2, I consider that this divergence from the law of deceit is more than a mere triviality-it has both

* Teaching Fellow, Durham Law School (UK); Barrister of Lincoln's Inn.

1 The Regulation, by art 8d, inserts art 35a into Regulation (EC) 1060/2009 of 16 September 2009 on credit rating agencies [2009] OJ L302/1, affording investors or issuers a civil claim for damages against CRAs, subject to certain provisions (discussed below). 
practical and legal implications. The practical implications arise from the global reach of English law in the debt markets. For example, English law governs more sovereign bonds than the law of any other country, and the majority of those bonds are listed outside of London and denominated in currencies other than sterling. The legal implications are two-fold. ${ }^{2}$ Firstly, it must be considered what role is left for domestic law in the context of rating agency liability. Secondly, there is a broader theoretical point to be made in terms of the potential harm to taxonomy and, ultimately, to the rule of law that could be brought about by continued resort to specific, directly effective civil liabilities without careful consideration of the domestic context over which they impose themselves.

It is worth considering, briefly, the background against which this debate is set. CRAs are, at best, perceived as having underestimated the risk inherent in much of the world's debt and, at worst, are alleged to have deliberately changed rating models to increase the apparent credit worthiness of the booming subprime collateralised debt market. That is not, of course, to suggest that such action was fraudulent (despite the fact that, in January 2015, Standard \& Poors (S\&P) settled charges of fraudulent misconduct brought by the US Securities and Exchange Commission), though it was perhaps in response to market pressures. ${ }^{3}$ As issuers began to structure products with significant concentrations in one market (such as in subprime residential mortgages), there was considerable pressure on the CRAs to adjust their models to produce greater tranches of AAA-rated debt ${ }^{4}$ within investment vehicles. ${ }^{5}$ For example, in 2004, Moody's, the second largest CRA, ${ }^{6}$ stopped using the binomial expansion ratings model, which favoured diversity in a portfolio, but then did not commit 'nearly enough resources to get the ratings

2 Issam Hallak, 'Governing Law of Sovereign Bonds and Legal Enforcement' in Robert W Kolb (ed), Sovereign Debt: From Safety to Default (Wiley 2011) 208.

3 US Securities and Exchange Commission, 'SEC Announces Charges Against Standard \& Poor's for Fraudulent Ratings Misconduct' (US Securities and Exchange Commission, 21 January 2015) <www.sec.gov/news/pressrelease/2015-10.html> accessed 6 January 2016.

4 AAA-rated debt are gold-standard, highest quality debt. They are the least likely to default of any tranches of debt.

5 See generally John M Griffin and Dragon Y Tang, 'Did Credit Rating Agencies Make Unbiased Assumptions on CDOs?' (2011) 101(3) AER 125.

6 In the first half of 2007, Moody's rated 91.2 per cent of the US asset and mortgage-backed securitisation market, second only to S\&P. See Asset-Backed Alert 'Rating-Agency Shares of US ABS and MBS in the First Half' (30 June 2007) <https://www.abalert.com/rankings. $\mathrm{pl}$ ?Q=102> accessed 10 May 2016. 
right' to reflect changing correlative risk. ${ }^{7}$ S\&P, similarly, were alleged not to have allocated resources to improving the analytics because improving the model would not add to S\&P's revenues. ${ }^{8}$ The progression to more issuer-friendly ratings was clearly not uncontroversial. Nevertheless, it did not facilitate claims against CRAs in the UK. This is because the lack of proximity between CRAs and investors renders a claim in negligent misstatement difficult to establish. This difficulty is aggravated in a claim of fraud (or deceit) because such claims require proof of an intention to deceive. ${ }^{9}$

The influence of firms such as Moody's, S\&P, and Fitch was so significant that, in effect, they operated as gatekeepers to the debt market. ${ }^{10}$ By issuing a poor rating, they could effectively price smaller issuers out of the market. Even governmentbacked liquidity schemes, such as the Bank of England's 2008 Special Liquidity Scheme, required eligible debt to be rated AAA or equivalent by at least two of S\&P, Moody's, and Fitch. ${ }^{11}$ It was for similar reasons that there were only a few rating agencies. Due to the pressure on issuers to compete, there was little incentive to have their products rated by relatively small or unknown CRAs, whose ratings carried less gravitas than those of larger firms. In sum, the CRAs commanded considerable influence over a global market (involving private and state actors), which was not always exerted with the care or accuracy that circumstances demanded. ${ }^{12}$ The EU's-and the United States'-decision to regulate the CRA market more keenly is thus unsurprising.

7 US Senate, Permanent Subcommittee on Investigations, Wall Street and the Financial Crisis: Anatomy of a Financial Collapse (112 S Hrg 675) 293.

8 ibid 292.

$9 \quad$ Derry $v$ Peek (1889) 14 AC 337 (HL) 374.

10 Matthias Lehmann, 'Civil Liability of Rating Agencies: An Insipid Sprout from Brussels' (2014) LSE Law, Society and Economy Working Papers 15/2014, 3 <http://www.lse.ac.uk/collections/ law/wps/WPS2014-15_Lehmann.pdf> accessed 12 January 2015; See also, Franz P Hops, 'Problems and Reforms in Mortgage-Backed Securities: Handicapping the Credit Rating Agencies' (2009-2010) 79 Miss LJ 531, 535.

11 Bank of England 'Special Liquidity Scheme: Market Notice' (21 April 2008) <http://www. bankofengland.co.uk/markets/Documents/money/marketnotice080421.pdf $>$ accessed 14 February 2015.

12 See, eg, Bathurst Regional Council v Local Government Financial Services Pty Ltd (No 5) [2012] FCA 1200, in which S\&P was found to have breached a duty of care to investors by awarding a AAA rating to a highly volatile instrument (it lost c. 90 per cent of its value in fewer than 24 months). 


\section{Duplication of laws}

\subsection{Article 35a liability}

The background set out above does not elucidate why the regulation of CRAs necessitated the inclusion of a directly effective civil law action against CRAs. This latest Regulation (the Regulation) ${ }^{13}$-the third of its kind since 2009-affords investors a private cause of action ${ }^{14}$ against a CRA if loss is suffered as a result of an agency committing, intentionally or with gross negligence, any one of over 80 regulatory infringements, where that infringement has an impact on a credit rating. These infringements, listed in Annex III of the 2009 Regulation ${ }^{15}$ include, for example, a CRA's failure to assess 'whether there are grounds for re-rating or withdrawing an existing credit rating; ; ${ }^{16}$ a CRA's failure to ensure that 'the provision of an ancillary service does not present a conflict of interest with its credit rating activity'; ${ }^{17}$ a CRA's introduction of 'compensation or performance evaluation contingent on the amount of revenue that the credit rating agency derives from the rated entities'; ${ }^{18}$ and a CRA's failure to use 'rating methodologies that are rigorous, systematic, continuous and subject to validation based on historical experience, including back-testing. ${ }^{19}$ Put simply, these regulatory requirements aim to ensure the accuracy and fairness of credit rating.

It is not within the remit of this paper to analyse the regulatory requirements. The focus, rather, is on the imposition of additional civil liability under Article 35a of the Regulation. It is possible to contend both that the Annex III requirements are sound and that the liability contingent on infringement is not. The civil liability is clearly dependent on some sort of factor capable of breach as provided in Annex III. However, those Annex III requirements do not depend on EU statutory liability for their relevance. For example, one could imagine the Annex III requirements

See above (n 1).

Art 35a was into Regulation (EC) 1060/2009.

Annex III was inserted into the 2009 Regulation by Regulation (EU) 513/2011 of 11 May 2011 amending Regulation (EC) 1060/2009 on credit rating agencies [2011] OJ L145/51, art 1 para 27.

Regulation (EC) 1060/2009 (n 1) Annex III, I No 21.

ibid I No 23.

ibid I No 41.

ibid I No 43. 
forming a guideline for assessing, say, a breach of a standard of care in an action for negligent misstatement in the UK. There is also something to be said for harmonising credit rating practice across member states. So, to reiterate, Annex III is arguably of merit, and one need not disagree with that proposition in order to consider that Article 35a was unnecessary or undesirable, or both.

There are certain features of this liability that warrant consideration. Firstly, it is not the accuracy of the statement that triggers liability, but rather the intentional or grossly negligent commitment of an infringement (albeit that such an infringement must have 'an impact on the credit rating'). Such an observation may appear unremarkable, though it will be worth bearing in mind for what follows.

Furthermore, the infringement must, of course, require intention or gross negligence-mere negligence will not suffice. ${ }^{20}$ The Regulation leaves it to the individual member States to define the terms 'intention' and 'gross negligence'. In the UK, gross negligence is generally understood to mean no more than negligence 'with the addition of a vituperative epithet. ${ }^{21}$ However, for the purposes of CRA liability, 'gross negligence' has been understood to mean recklessness. ${ }^{22}$ Recklessness relates not to breach of a standard (as is the case of negligence), but to intention. Specifically, that the defendant acts recklessly with respect to:

(i) a circumstance, when he is aware that a risk exists or will exist; or

(ii) a result, when he is aware of a risk that it will occur,

and it is, in the circumstances known to him, unreasonable to take the risk. ${ }^{23}$

Thus, the focus of the cause of action in recklessness is different from that of negligent misstatement (which is concerned with the failure to meet a reasonable standard of care). The cause of action against a CRA will require the claimant to prove, at a minimum, that the CRA was careless as to the risk of infringement, not that they happened not to meet an objective standard of care.

20 Regulation (EC) 1060/2009 (n 1) art 35a, para 1.

21 Wilson v Brett [1843] $11 \mathrm{M} \& \mathrm{~W} 113,115$ (Baron Rolfe).

22 HM Treasury, Explanatory Memorandum to the Credit Rating Agencies (Civil Liability) Regulations 2013 (Cmd 1637, 2013) 7.5.

$23 R v G$ [2003] UKHL 50, [41] (Lord Bingham), affirming the earlier case of $R v$ Cunningham [1957] 2 QB 396. 


\subsection{English tort of deceit}

English private lawyers will recognise that this formulation resembles the English tort of deceit. Deceit consists in the making of a false statement, knowing it to be false, or 'recklessly, careless whether it be true or false, ${ }^{24}$ and the claimant then acts to his or her detriment in reliance on it.

Professor Möllers and Ms Niedorf, discussing the new Regulation, contend, however, that this is not deceit because deceit requires misrepresentation of fact, rather than of opinion. ${ }^{25}$ Furthermore, they contend that, in any event, the claimant will have to show that the defendant lacked reasonable belief in the truth of the statement, thus rendering any claim in the tort of deceit very unlikely. ${ }^{26}$ To this, a third possible objection could be added, ie deceit requires an intention that the claimant relies on the statement. In the context of ratings requested by the issuer, and made publicly available, such a class would either be restrictively narrow (ie, those whom the CRA specifically knew would act in reliance on their statement) or fancifully wide (ie, those who would rely on the statement, if they were to act).

However, it is respectfully submitted that such a conclusion rests on too simplistic a view of English tort law. For the sake of clarity, let us reiterate the alleged obstacles to deceit: (i) a statement of opinion cannot constitute deceit; (ii) even if the CRA was reckless as to a specific infringement, that is not proof that they lacked a reasonable belief in the statement itself; and (iii) it is not at all clear, given the context in which CRAs operate, that reasonable bounds can be placed on the intention element.

As to the first, it is submitted that a statement of opinion can, under certain circumstances, be regarded as a statement of fact for the purposes of tortious deceit. As to the second, the problem with the objection, if it relates to the law as it is (ie, post-Annex III requirements), is that it presupposes that recklessness as to the ultimate truth of the statement and recklessness with regard to a necessary precursor to the statement are somehow discrete. As to the third, intention in English law has long included oblique intention, where the outcome is a virtual certainty, even if

Derry v Peek (1889) 14 AC 337 (HL), 374.

Thomas M J Möllers and Charis Niedorf, 'Regulation and Liability of Credit Rating Agencies-A More Efficient European Law?' (2014) 11(3) ECFR 333, 355. ibid 356. 
not directly intended, ${ }^{27}$ and thus concerns relating to the size of the potential class of claimants are misplaced. Let us consider each in turn.

\subsubsection{Opinion can constitute fact}

Whilst it is true that statements of opinion do not normally constitute a statement of fact, numerous cases have held that a statement of opinion can-especially when it comes from a professional or competent party-contain within it an implicit representation of fact, that fact being that there are reasonable grounds for holding the opinion. For example, Lord Evershed MR in Brown $v$ Raphael $^{28}$ held that:

The representation was not merely confined to the fact that the vendor entertained the belief but also, inescapably, there goes with it the further representation that he, being competently advised, had reasonable grounds for supporting that belief. ${ }^{29}$

Similarly, Romer LJ, in his judgment in the same case, opined:

I should have thought that it was fairly obvious that the statement purporting to come, as it did come, from the vendor's solicitors, and expressing a belief vital in relation to this legal transaction, inevitably would suggest to the purchaser that the opinion was being expressed upon reasonable grounds; for it was a matter which everybody concerned, and especially a solicitor, must know would vitally affect the value of the reversion which the purchaser was proposing to buy (...). ${ }^{30}$

Brown LJ in Economides $v$ Commercial Assurance Co plc ${ }^{31}$ reiterated his statement from Brown, albeit to distinguish it, saying that the representation 'would inevitably carry with it the implication that there were reasonable grounds to support the belief. ${ }^{32}$ On the basis of these authorities, amongst others, ${ }^{33}$ one may at least conclude that opinions in professional contexts-especially where those opinions are vital to the transaction-carry with them an implied representation 
that there are reasonable grounds for the belief. It may, perhaps, be going too far to suggest that all opinions carry with them such representations, though one can comfortably assert that opinions from CRAs-being both professional and vitalcarry with them such implied representations of fact.

\subsubsection{Annex III infringement renders opinions unreasonable}

In the absence of Annex III (or any specific requirements) it would be difficult to establish the grounds for asserting that a CRA lacked a reasonable belief in the truth of its statement. While not impossible, any inquiry must first establish what constitutes 'reasonable grounds', even before matters of proof are considered. The main benefit of the specified infringements listed in Annex III is that they can provide clear guidelines for determining when a rating will be reasonable (the conceit being that an infringement renders the rating unsound-otherwise what point is the requirement?). There is a sound logic in this position, as is clear when one considers the alternative: can the law, on the one hand, hold that a rating can be sound only if the agency undertaking the rating has avoided all specified infringements, while, on the other, stipulate that the agency can have reasonable grounds for believing its statement regardless of whether it avoided the infringements? Clearly not: such an assertion would be hopelessly inconsistent.

\subsubsection{Intention}

It is fairly settled law that, in order to succeed in a claim for deceit, the claimant needs to show that the defendant intended that the claimant would act on the representation and not, for example, that the statement was made to the claimant in particular, or that he would suffer harm as a result. ${ }^{34}$ This is important. For example, there can be no doubt that May LJ, in his judgment in Abu Dhabi Investment Co $v \mathrm{H}$ Clarkson \& $\mathrm{Co}^{35}$ was incorrect in asserting that deceit required 'an actual intention to deceive the claimant. ${ }^{36}$ Firstly, a reasonable reading of the authority ibid [33]. 
cited by his Lordship does not support such a conclusion. The authorities are not considered in any detail in the judgment, but, inasmuch as they deal with the specific issue of intention at all, they confirm the aforementioned position-that the defendant must intend the claimant act on the statement. ${ }^{37}$ Secondly, and far more fundamentally, were this the case, then the tort of deceit would undermine itself, at least in instances where the defendant was reckless as to the truth of the statement. That is, how can one at once intend that the claimant actually be deceived while simultaneously not caring about the truth of the statement? ${ }^{38}$ While you may not honestly believe what you are saying, that does not mean you honestly believe you are lying. There is a subtle but important difference between intending that someone act on a statement you neither know nor care is true, and intending for someone to believe an untruth. May LJ appears, perhaps, to have conflated the concepts.

With that in mind, it is worth noting two important caveats. Firstly, the claimant need not be specifically identifiable with regard to intention; it is sufficient that the claimant belongs to a class of persons. ${ }^{39}$ Secondly, the defendant need not have primarily or explicitly intended that the claimant would act on the statement; it is sufficient that such was a virtual certainty (as noted in Woollin above).

How, then, should the intention requirement be interpreted with respect to CRAs? Put at its most restrictive, one could argue that the defendant ought to be virtually certain that everyone within a class of persons would act on the basis of the statement. This argument has the merit of being a largely literal interpretation of the law. Thus, the CRA would have to know that: (a) a pool of people would act on the basis of their statement-not might, would; and (b) this pool of people will not necessarily include just those who have already chosen to invest in the relevant security but will also include people with whom the CRA has no legal relationship, ie, people who are still deciding whether to invest. However, by expanding the class to include those who may invest (and, by extension, who may not invest, and those

Eg, in Bradford Third Equitable Benefit Building Society v Borders [1941] 2 All ER 205 (HL), 211 - a case and page specifically cited by May LJ - it was clearly stated that the false statement 'must be made with the intention that it should be acted upon by the plaintiff' (Viscount Maugham); See also, Jones, Dugdale and Simpson (n 27) para 18-01-also cited by May LJin which it is clearly stated that intention in deceit means that the defendant 'intends that the claimant should act in reliance on [the false representation]'.

38 L C H Hoyano, 'Lies, Recklessness and Deception: Disentangling Dishonesty in Civil Fraud' (1996) 75 Can Bar Rev 474, 487. 
who could not care less either way), it becomes impossible to assert that the CRA could be virtually certain that they would act on the basis of the statement. The literal interpretation, then, becomes self-defeating.

A second interpretation fits more comfortably with common sense and avoids the logical conflict. It should be sufficient that, in making a statement, CRAs can be virtually certain that some people within the class will act. The sense in this proposition becomes apparent if we remove ourselves from the amorphous realm of speech. Consider this: I own a car and, in a moment of questionable judgement, decide to loosen significantly all of the wheel-nuts before driving down the motorway. That one or more of my wheels will come off is a virtual certainty; I intend or am at least reckless as to this outcome. That other drivers will be affected by the resulting disaster is also a virtual certainty, as I obliquely intend that members within a class (motorway users) will be affected by my action. But can I say with any certainty that you-as another driver and thus member of that class of motorway drivers-will be affected by it? Of course not. Yet were I to crash into you-and ignoring other relevant laws for the sake of the hypothesis-one would never wish to deny your claim for damages simply because I had not intended that you would be affected. Indeed, it would have been wholly unrealistic for me to suppose that all members of the class would be affected; the fact that it is only one member of that class who was affected should not diminish my liability to that member. And so it is with deceit.

Thus, a CRA can be held to have intended that a claimant would act on the rating, on the proviso that the claimant belongs to that class of persons who are virtually certain to act on the basis of a rating. It is, for example, difficult to see why professional investors ought not to be regarded as such a class. To those more used to the realm of negligence, this net seems to be cast very wide; absent the limiting factor of proximity, we seem left with something more closely resembling reasonable foreseeability. Though, of course, this is not negligence. There would seem very little reason for limiting liability in fraud to similar extents.

What has been established, then, is that the current English tort of deceit, fortified by Annex III, achieves at least as much as the Article 35a civil law action. CRAs are professional, often privy to information inaccessible to others, and thus their opinions carry with them an implied representation that there are reasonable grounds for holding those opinions, and this places it squarely within the purview of the law on deceit. Such an observation may appear trifling-on its own, it probably would be-but it is demonstrative of a quick-fix approach to law that is troubling, as shall be demonstrated in the following sections. 


\section{Taxonomic objections}

\subsection{Specific conflicts in CRA liability}

One of the fundamental problems with duplication of laws actually arises from inexact duplication. This is the problem here. Article 35a(1) states that:

An investor may claim damages under this Article where it establishes that it has reasonably relied (...) on a credit rating for a decision to invest into, hold onto or divest from a financial instrument covered by that credit rating.

Taken on its own terms, the requirement is not without possible justification: one suspects that the requirement of reasonable reliance is partly to ensure that investors are not at liberty to make risky investments effectively underwritten by the CRAs. That being said, the requirement of reasonable reliance does seem out of place in an article concerned with intentional or grossly negligent infringement. ${ }^{40}$ However, there exists no such requirement in tortious deceit. All that is required in this respect is that the claimant relied on the statement, not that the reliance was in any way reasonable. The claimant's own lack of care may be a defence to a claim in negligence, but it does not apply to deceit. ${ }^{41}$

This leaves the current law in something of a quandary: if Article 35a is to sit alongside domestic law, then whatever justification the reasonableness requirement may have, it is undone by basic civil fraud. This may not be true in all member states, of course; however, if that is the case, then there are obvious implications for harmonisation. This would not be a problem if the sole objective of Article 35a were to impose a minimum standard of protection, a proposition that is admittedly not without some precedent. Arden LJ, in respect of conflicts between the UK's Equal Pay Act 1970 and Article 141 of the European Union Treaty in Wilson $v$ Health and Safety Executive, ${ }^{42}$ noted that Community law does not prevent member states from conferring greater rights to equal pay. ${ }^{43}$ Therefore, so long as domestic

40 There is a general requirement in private law that the parties be viewed as equal-see, eg, Ernest J Weinrib, Corrective Justice (OUP 2012) - which is respected by recognising the contributory negligence of the claimant; to ignore one party's negligence in favour of the other's is clearly unjust. It is not clear that the scales are so equally weighted where one party commits a wrong tantamount to fraud and the other party only commits negligence.

41 Central Ry of Venezuela $v$ Kisch (1867) LR 2 HL 99.

42 [2009] EWCA Civ 1074 (CA).

43 ibid [67]. 
law affords protection that is at least equivalent to that offered under Community law, it will be compatible with Community law. The analogous reasoning works inasmuch as both the Treaty and Article 35a liability afford protection by the grant of rights, ie the English law on deceit can be compatible with the Regulation if it affords greater protection to investors than the Regulation.

However, the equal pay protection afforded under the Treaty is based onand a logical corollary of - a core, foundational principle of the Community that prevents comparable situations being treated differently without justification. ${ }^{44}$ The Regulation is more removed from this tight logical relationship, and is less obviously based on a single principle against which we can judge the compatibility of national law. For example, domestic law could be judged to promote equal pay more effectively than specific Community laws, and thus still be compatible with Article 141. In this context, one cannot make a relevant argument that domestic law promotes investor protection more effectively than the Regulation, because the Regulation's explicit objective is regulation of CRAs, and not investor protectioneven if the latter is the overriding rationale. If harmonisation is a principle on which the Regulation is based, then such will be of little comfort to those seeking to promote better protection through domestic law.

In the alternative, then, we must consider that the Regulation supersedes domestic laws of deceit, at least in respect of CRAs, on the basis that tortious deceit conflicts with one of the substantive provisions of the Regulation (and who is to say that Article 35a(1) concerning reasonable reliance is any less substantive than the rest of Article 35a?). Such would, of course, be the traditional interpretation of Regulations. ${ }^{45}$ It seems particularly odd for the rules on fraud to be altered in a contingent manner, and yet more odd for CRAs to receive greater protection from claims arising from their own fraudulent acts than is afforded to those whose fraud may cause less systemic harm, viz. every other legal person under that governing law. The Council probably did not consider that this liability amounted to fraud in the first place, but such an observation does not change the fact that it does so in England and Wales, nor does it help solve the conundrum. Such conflicts are bound to occur again in other guises, so long as quick-fix solutions are found in

45 Case 39/72 Commission of the European Communities v Italian Republic [1973] ECR 101, [4]: 'It cannot be accepted that a Member State should apply in an incomplete or selective manner provisions of a Community Regulation (...). 
directly effective specific civil actions, imposed upon otherwise long and carefully considered law. This is not wanton criticism; it is a fact.

\subsection{General theoretical considerations}

Bizarre though this situation may be, there is a sense in which we are where we are, for now at least. In the final Part of this paper, it is apt briefly to consider some of the more theoretical aspects of this problem, if only as a guide for future decisionmaking.

Of the many possible defining characteristics of the rule of law, few can be so certain as the requirement that the law must be accessible and intelligible to those who would fall within its purview. Accessibility would require that the law does not regulate the same wrong-the term 'wrong' is used in the sense of a legal category, rather than merely meaning the same 'act' - under different regulatory regimes. We accept, of course, that certain actions may violate a number of different principles: a breach of contract may violate contractual and tortious principles, just as a criminal act may generate both criminal and civil liability. But one may rightly question a law that regulates varyingly an act violating just one legal principle. Similarly, for the law to be intelligible, it must, inter alia, be possessed of internal consistency, of a unity of meaning; if the law is to be a creature of reason, then internal contradictions are certainly a sign of misunderstanding or poor reasoning, and thus to be avoided. For example, it is a troubling oddity of the English (and not just English) common law that fraud 'vitiates all transactions known to the law $^{46}$ - except, of course, where that fraud relates to inducement to engage in sexual activity, where, save in certain exceptional circumstances, consent to sex will not be vitiated by fraud. ${ }^{47}$ This is not to argue that the law is to become slave to language, but evidently there is not a clear understanding of some element ofin this example-either fraud, or consent, or rape law. Fundamentally, the law, if

46 Lazarus Estates Ltd v Beasley [1956] 1 QB 702 (CA) 722 (Parker LJ).

47 See, eg, $R v$ Flattery (1877) 2 QBD 410; $R v$ Clarence (1888) 2 QBD 23, 43: 'the proposition that fraud vitiates consent in criminal matters is not true' (Stephen J). It is not suggested that such should necessarily be the case in rape law, but rather that such a contradiction may denote a more fundamental conceptual problem; For a thorough exposition of the subject, see especially Jed Rubenfeld, 'The Riddle of Rape-by-Deception and the Myth of Sexual Autonomy' (2013) 122 Yale LJ 1372. 
it is to be fair, must be consistent; if it is to be consistent, it must eschew flawed taxonomy and internal contradiction.

The aforementioned golden thread is important for understanding any system of law. Just as we may ask what makes dogs and wolves different enough to be of different subspecies, but similar enough to be of the same species, we may ask what marks the essential difference between negligence occasioning physical harm and negligence occasioning economic loss; or-conversely_-what, despite evident differences, unifies them when compared with, say, contract law. The example is not wanton. Tort law in England has developed in a piecemeal fashion, and, despite notable attempts to find irreducible core elements, remains largely diffuse. ${ }^{48}$ There is something to be said for pragmatism over formalism, of course, but there will come a point at which pragmatism must yield to the requirement that like cases be treated alike. It is clearly not enough simply to assert that 'tort is the realm of legal wrongs', and thereafter list the many and various wrongs that constitute tort. One needs to ask what is meant by wrong that makes tortious wrongs different from, say, criminal wrongs or-more pertinently for private law-from the 'wrong' of breach of contract. It is also worth asking what it is that entitles torts to belong to the same taxonomic group beyond merely asserting that they do not belong in a different taxonomic group (what, for example, unites defamation and negligent misstatement?). This is not to say that there are not some answers to these questions - and certainly this paper is not the forum to consider them all-but it is important that we ask the questions; without clear taxonomic understanding, we cannot hope to decide like cases alike.

Perhaps these considerations speak for themselves, but it should be abundantly clear that a growing archipelago of small islands of liability from the EU-albeit that EU law is in a different but overlapping legal taxonomy-can only serve to obfuscate and to sever nascent golden threads. They render illusory any coherence in our law, which 'is liable to be affected whether the basic approach of some area of law is changed or whether some ill-fitting and largely unnecessary principles are superimposed on to it. ${ }^{49}$ It would be one thing if those islands of liability were addressing gaps in the national law-and no doubt some do and will-though, as has been shown herein, this is not always the case.

The most notable of which-at least for its prominence-is that of Lord Atkin in Donoghue v Stevenson [1932] AC 562 (HL) 580.

Lady Justice Arden, 'Peaceful or Problematic? The Relationship Between National Supreme Courts and Supranational Courts in Europe' (2010) 29(1) YEL 3, 5. 


\section{Concluding remarks}

Though much of the CRA regulatory regime that now exists in the EU is to be commended, as it provides guidelines vital to ensuring long-term confidence (if not stability) in the potent debt markets, the creation of directly effective liability remains both a mystery and a problem. Why the same could not have been achieved through a Directive is confounding. The end result is a near duplication of tortious deceit in England and Wales-fraud, by any other name-except it did not even manage exact duplication (in the matter of reasonable reliance). Accordingly, where there would have been mere confusion, there is now genuine conflict, a conflict that seems to resolve itself by affording CRAs greater protection against liability for fraud than is afforded to any other actor. Whilst the final subsection in this paper may have seemed somewhat removed from the rest of the discussion, given that Article 35a is already with us, it is in many respects the most important. For as long as we classify our private law by causative events-like unjust enrichment, or breach of contract, or deceit-we must never allow ourselves to fail to understand that causative event, lest we lose sight of what makes those whom we make liable actually liable. The quick-fix civil liability in the Regulation takes us one further step into the morass of ill-defined and inconsistent private liabilities. 